\title{
Mitigating natural events to avoid disaster in public school buildings: seismic retrofitting of SDN 42 Korong Gadang
}

\author{
James Mwangi ${ }^{1}$, Laura Putri $^{2, *}$, and Listhbeth Collins ${ }^{3}$ \\ ${ }^{1}$ Architectural Engineering Department, California Polytechnic State University, 1 Grand Ave., San Luis Obispo, CA 93407, \\ USA \\ ${ }^{2}$ Build Change, J1. Kemuning No. 2, Komplek Perumahan Dangau Teduh, Padang, 25162, Indonesia \\ ${ }^{2}$ Build Change, 535 16th St., Suite 605, Denver, CO 80202 , USA
}

\begin{abstract}
With over 50 million students, Indonesia has the fourth largest education system in the world. The first twelve years of education are compulsory for all citizens. The students, together with over 3 million teachers spend six (or five in some cases) days a week at over 300,000 schools, typically from 6:30 AM to 2 (or 3) PM. Geographically, Indonesia is traversed by the infamous "ring of fire" and prone to natural events resulting from the tectonic plate movements of the Australian Plate from the South, the Eurasian and Sunda Plates from the North and the Philippine Plate from the East. Left unmitigated, these natural events would lead to natural disasters emanating from resulting earthquakes and leading to tsunamis, landslides, the collapse of building structures and failure of lifelines (roads, pipelines, electrical grid, etc.). In an effort to provide disaster-safe schools, the National Agency for Disaster Management has required that school facilities be a community center in case of disasters and serve as emergency shelters. Retrofit of existing buildings will be needed to comply with government guidelines. This paper presents a case study of the determination of structural deficiencies of an existing school building in SDN 42 Korong Gadang, Padang, West Sumatra and implementation of a seismic retrofit (design and construction) at the same building to mitigate potential earthquake disaster.
\end{abstract}

\section{Introduction}

With over 50 million students, Indonesia has the fourth largest education system in the world. The first twelve years (6 - primary school, 3 - junior secondary (or middle) school and 3 - high school) of education are compulsory. The students, together with over 3 million teachers spend six (or five in some institutions) days a week in over 300,000 schools typically from 6:30 AM to 2 (or 3) PM. The majority of schools (93\%) are public schools while $7 \%$ are private schools. The Ministry of National Education oversees $84 \%$ of the government schools while the remaining $16 \%$ are under the Ministry of Religious Affairs. Primary schools comprise about $72 \%$ of all schools while middle schools and high schools constitute $17 \%$ and $11 \%$, respectively. Each ministry is responsible not only for the education aspect of their schools but also the school facilities including the construction and maintenance of the school buildings.

Geographically, Indonesia is traversed by the infamous "ring of fire" and prone to natural events resulting from the tectonic plate movements of the Australian Plate from the South, the Eurasian and Sunda Plates from the North and the Philippine Plate from the East (Fig. 1.)

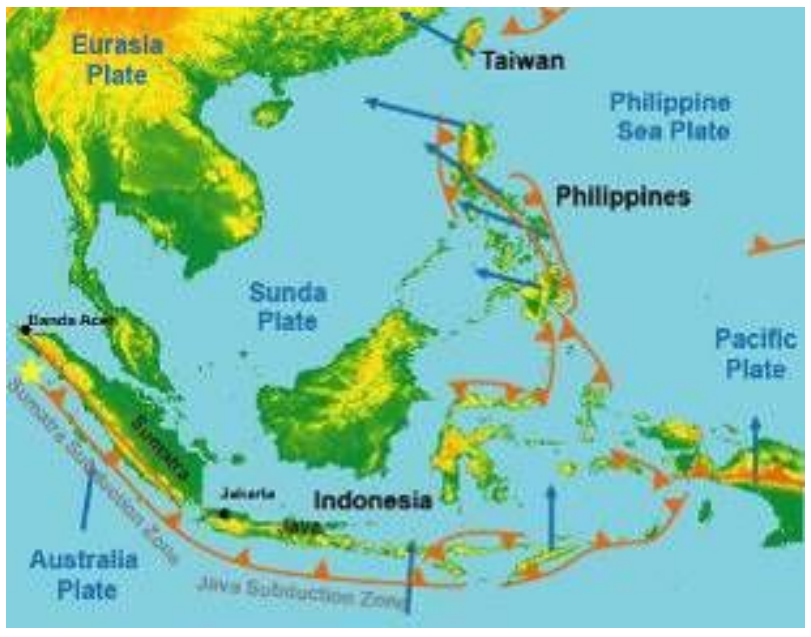

Fig. 1. Tectonic plate movements in Indonesia (source [1])

Recently, the plate movements have led to earthquakes that resulted in the loss of life as shown in Table 1. [2]. The table only shows events that had more than 20 casualties. Earthquakes are the risk most affecting the life and health of the population in Indonesia. 
Table 1. Recent earthquakes in Indonesia

\begin{tabular}{|c|c|c|c|}
\hline Location & Date & $\begin{array}{c}\text { Magnitude } \\
\left(\boldsymbol{M}_{\boldsymbol{w}}\right)\end{array}$ & Casualties \\
\hline Sumatra & 07-Dec-2016 & 6.5 & 104 \\
\hline Sumatra & 02-Jul-2013 & 6.1 & 42 \\
\hline Sumatra & 25-Oct-2010 & 7.7 & 435 \\
\hline Sumatra & 30-Sept-2009 & 7.6 & 1,117 \\
\hline Java & 17-Jul-2009 & 7.0 & 81 \\
\hline Sumatra & 12-Sept-2007 & 8.5 & 23 \\
\hline Sumatra & 06-Mar-2007 & 6.4 & 68 \\
\hline Java & 17-Jul-2006 & 7.7 & 668 \\
\hline Java & 26-May-2006 & 6.4 & 5,780 \\
\hline Sumatra & 28-Mar-2005 & 8.6 & 1,346 \\
\hline Sumatra & 26-Dec-2004 & 9.2 & 283,106 \\
\hline
\end{tabular}

It is clear that Sumatra has received the brunt of the earthquakes. A closer look at the Sumatra island shows the right strike-slip Sumatran Fault running along the entire length of the island besides the Sumatran subduction zone (Fig. 2.). This dangerous combination of natural formation leads to the catastrophes experienced in the region from earthquake-related events like landslides, tsunamis and destruction of building and lifeline structures.

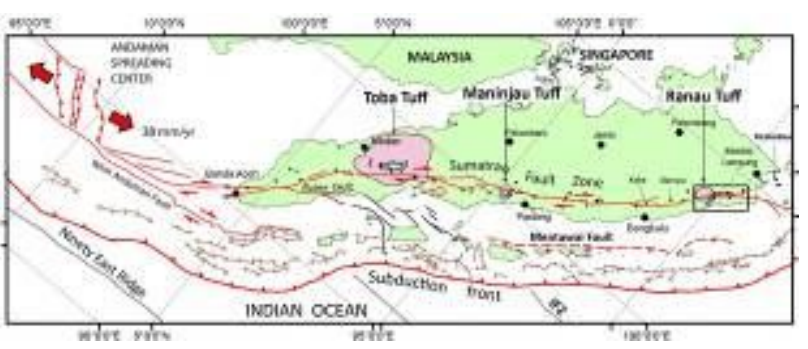

Fig. 2. Faults in Sumatra (source [3])

\section{Performance of school buildings in past earthquakes}

Both the ministries of National Education and Religious Affairs provide guidelines on the architectural layout and materials used in the construction of new public school buildings. There are also guidelines for rehabilitating existing public school buildings.

\subsection{Layout of existing buildings}

Classroom buildings are laid on a $7.0 \mathrm{~m}$ wide by $8.0 \mathrm{~m}$ module per classroom. The module is repeated for any number of classrooms as shown in Fig. 3. The layout is stackable to create two-story classroom buildings.

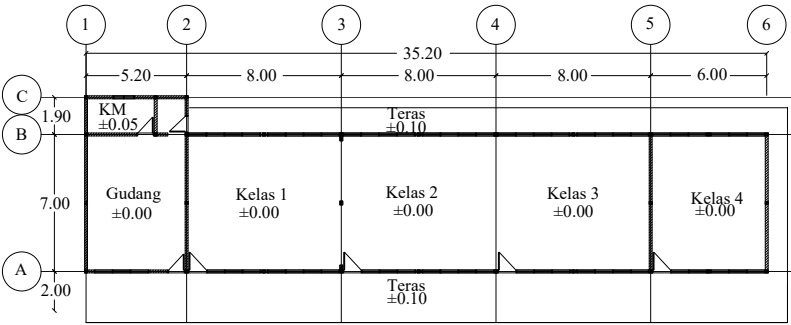

Fig. 3. Typical classroom building plan layout

The walls are built out of clay brick and reinforced concrete columns. There are large window openings for light and ventilation in the longitudinal direction. The transverse ends are either made of brick masonry gable ends or the hip roof slopes to the eaves as shown in Figs. 4. and 5 .

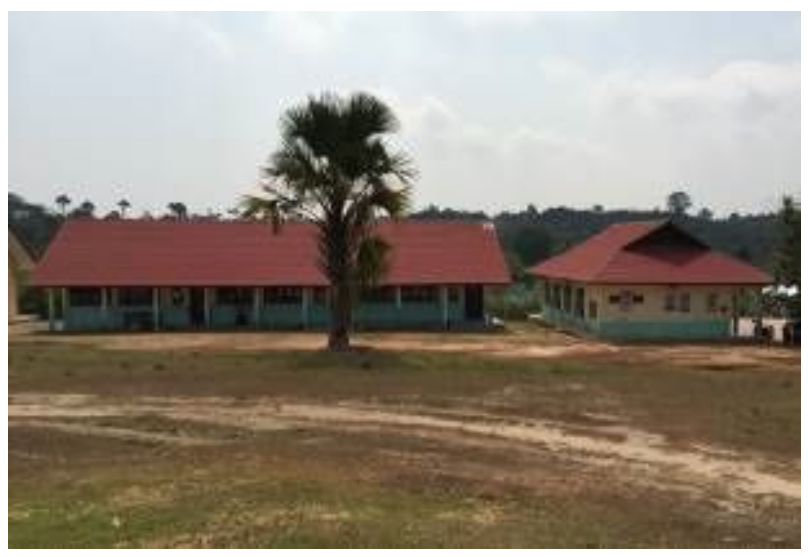

Fig. 4. Single-story school buildings layout

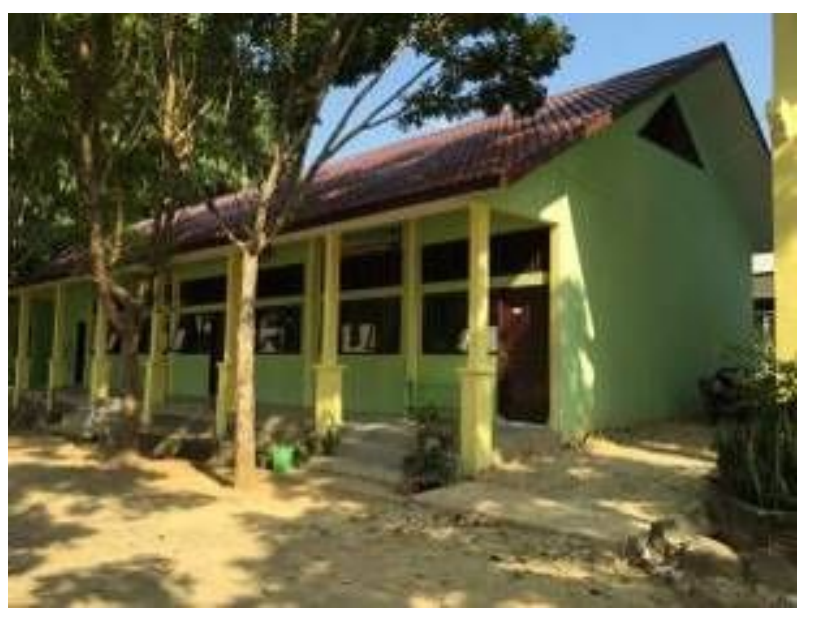

Fig. 5. Gable end of the school building

Fig. 6. shows a two-story school building that repeats the features of the one-story building.

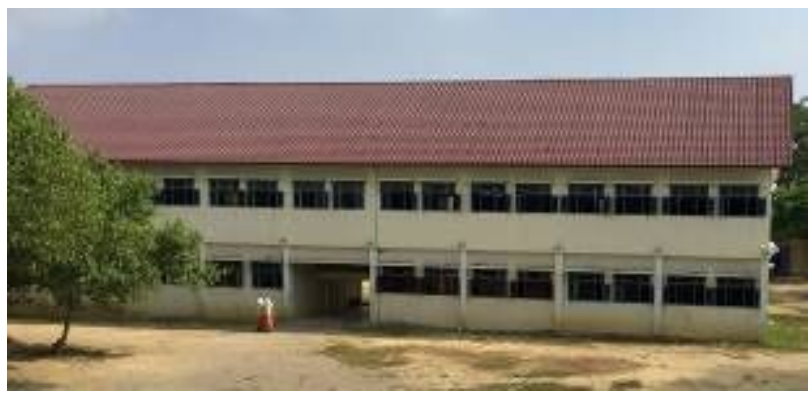

Fig. 6. Two-story school building layout

The high ceiling and the light roof are typically supported by wood or steel truss system as shown in Fig. 7. 

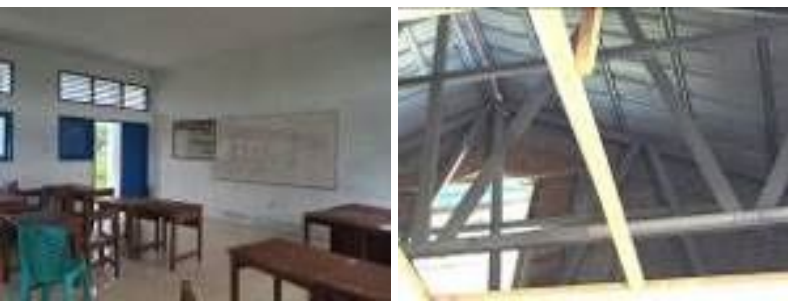

Fig. 7. School building ceiling and roof systems

\subsection{Observed Building Performance from Past Earthquakes and Other Events}

Schools located in low lands lacking adequate drainage are prone to flooding and interruption to educational activities as seen in Fig. 8.

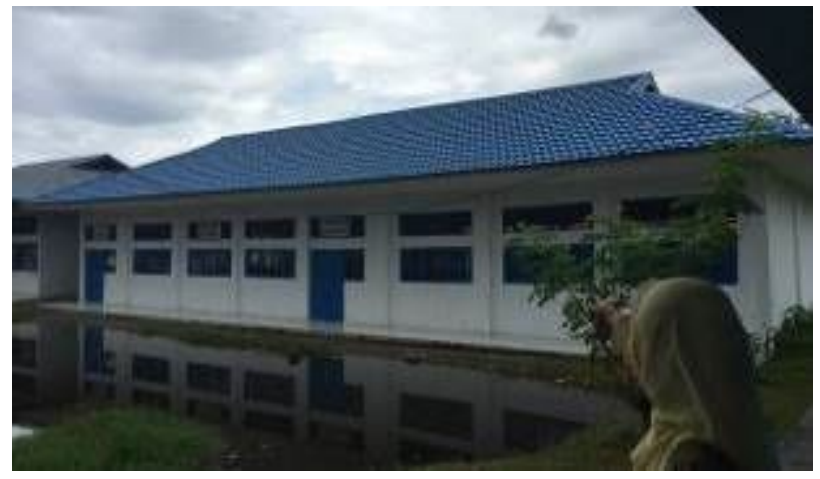

Fig. 8. Flooding at the school site

Geotechnical conditions at school sites are not adequately addressed lead to liquefaction and settlement related building failures as seen in Fig. 9. This can lead to building collapse and wall failure due to differential settlements.

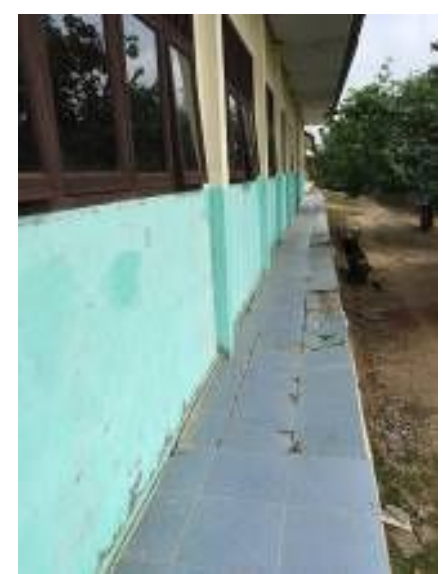

Fig. 9. The settlement at the school building

Other sites related hazards to school buildings include earthquake caused landslides as seen in Fig. 10.

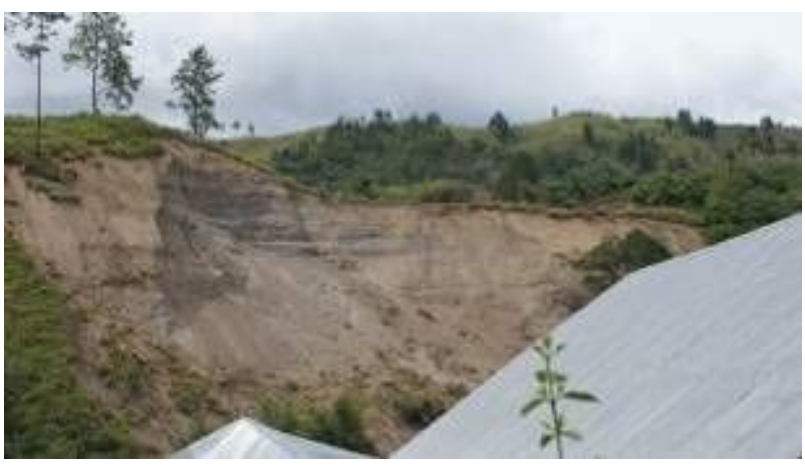

Fig. 10. Landslide at the school site

Damage to school buildings can be separated between structural and non-structural elements. Nonstructural failures in ceiling framing and heavy balcony guardrail walls have been observed as seen in Figs. 11. and 12.

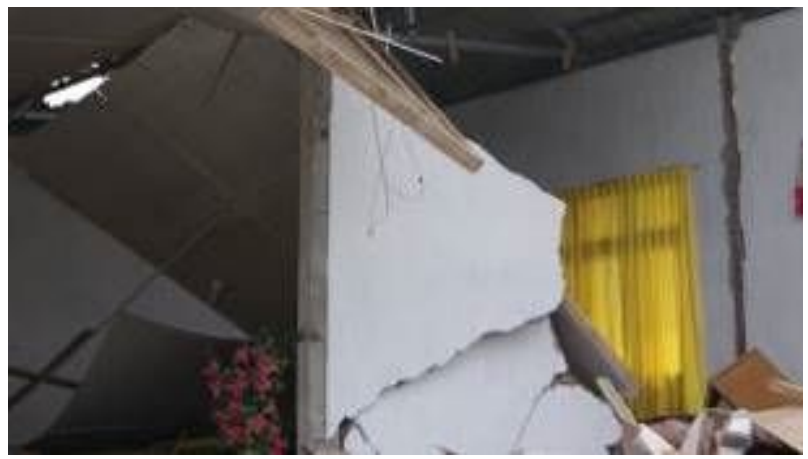

Fig. 11. The Ceiling collapse at the school building

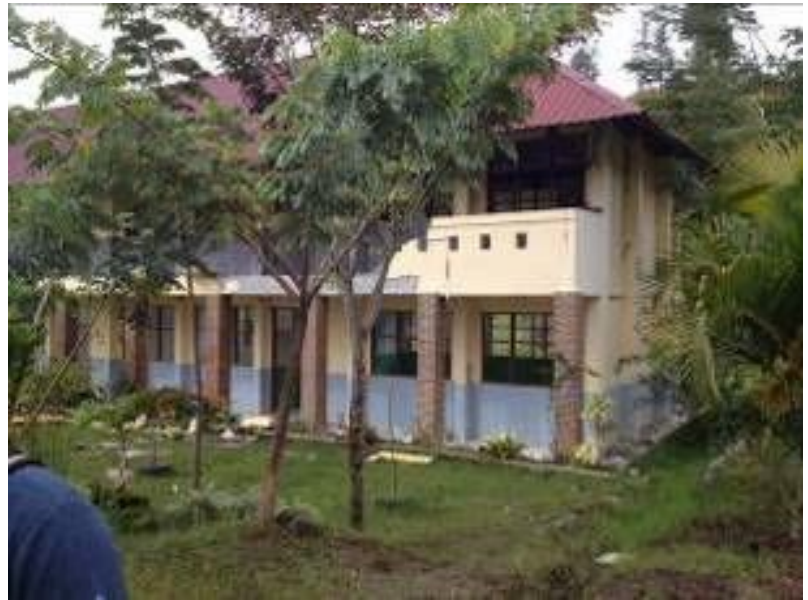

Fig. 12. Heavy balcony guardrail wall failure at the school buildin

Observed school building structural failures include total collapse as seen in Fig. 13. Other partial collapse failures occur as individual walls fail out-of-plane as seen in Fig. 14. or failure of the upper part of high heavy gable walls as seen in Fig. 15. 


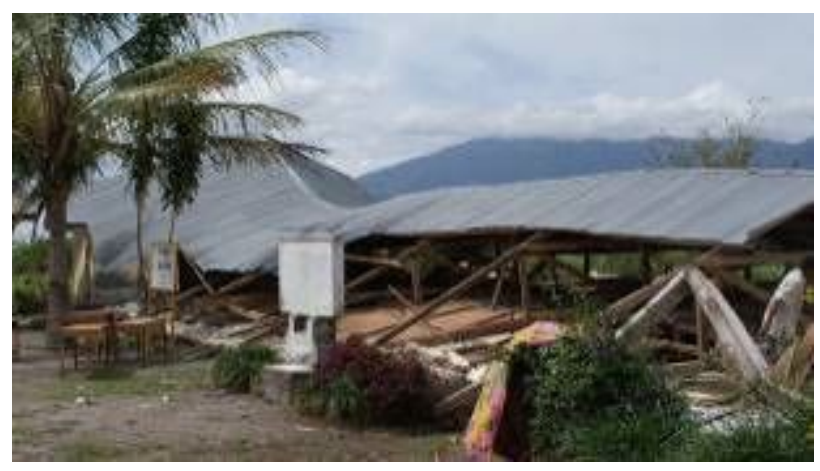

Fig. 13. Total collapse of the school building (Source: Dinas Pendidikan Aceh Tengah)

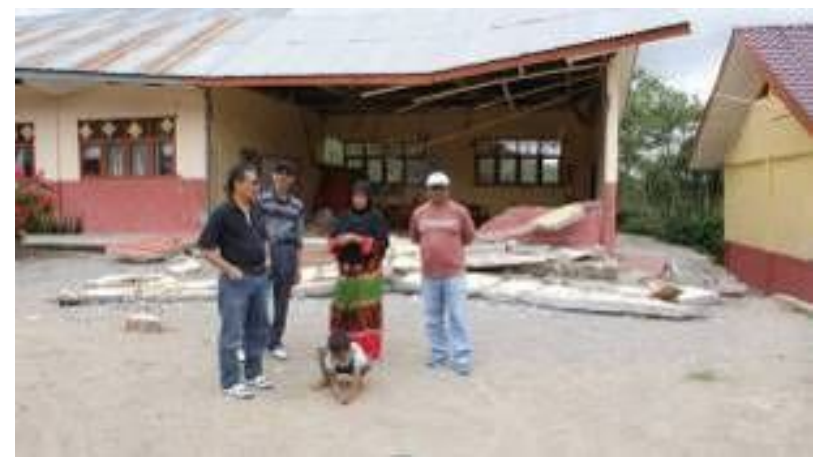

Fig. 14. Total wall collapse and failure at the school building (Source: Dinas Pendidikan Aceh Tengah)

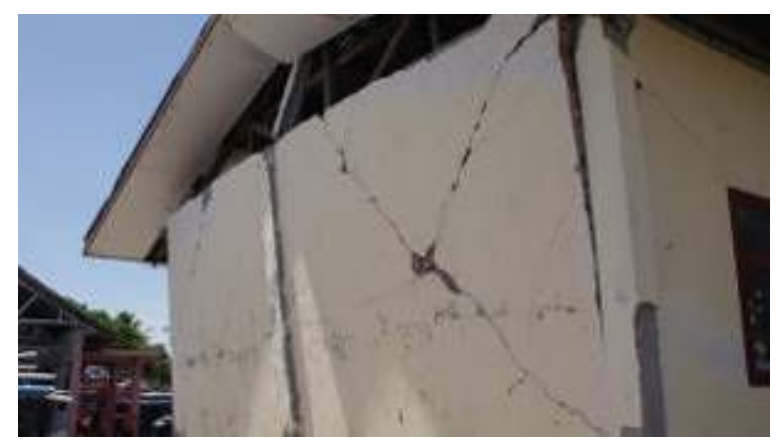

Fig. 15. Gable wall failure at school building (Source: Dinas Pendidikan Aceh Tengah)

Weak story-initiated failure of two-story school buildings has been observed as seen in Fig. 16 .

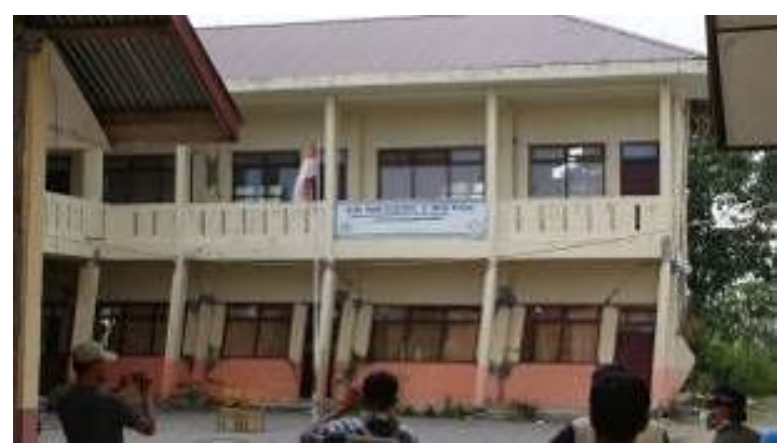

Fig. 16. Two-story school building failure (Source: Dinas Pendidikan Aceh Tengah)

\section{Seismic Retrofits of SDN 42 Korong Gadang}

The single class building A of SDN 42 Korong Gadang, Padang, Indonesia was retrofitted following evaluation of seismic deficiencies for both structural and nonstructural building components. The Indonesia National Standard specifications [4-9] were used so were the other school building design guidelines from the Ministry of Education [2],[10-14].

\subsection{Existing Deficiencies}

The existing school building plan is as shown in Fig. 17. which conforms to a required class layout. The roof is built of corrugated iron sheets over wood trusses. The walls are built of brick and reinforced concrete columns. Besides the two solid gable walls in the transverse direction, all the walls in the longitudinal directions have window and door openings as seen in the building elevations in Fig. 18.

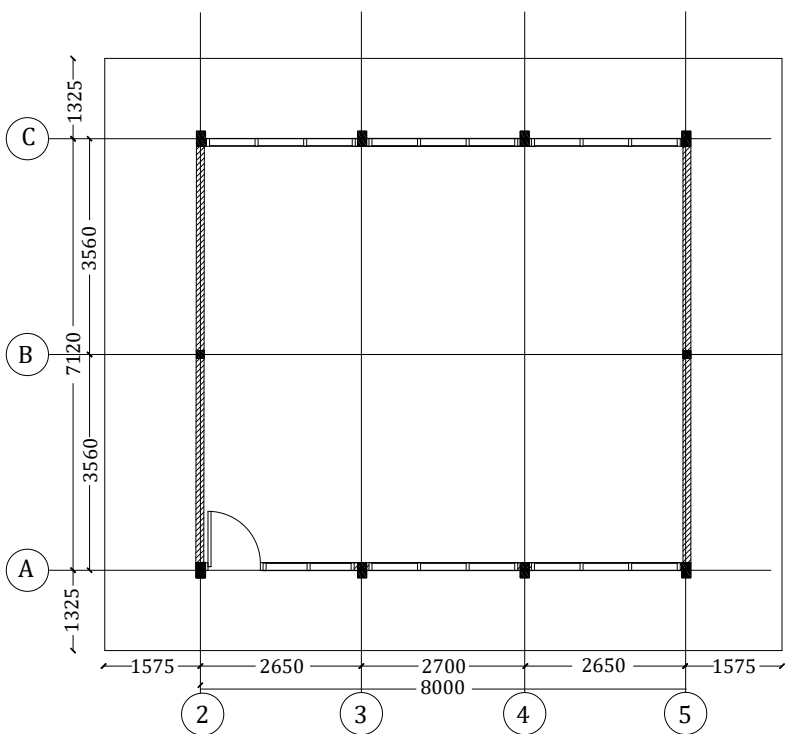

Fig. 17. Existing building A plan
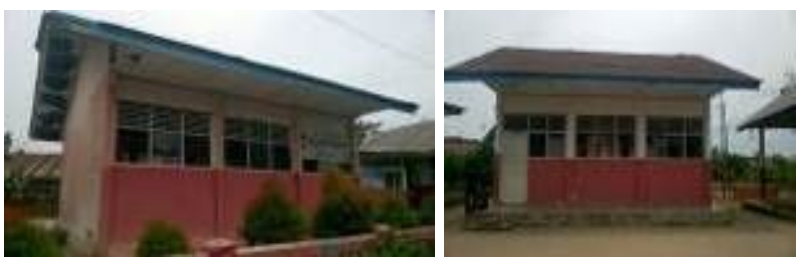

Fig. 18. Existing building A elevations

The building was found to lack of adequate shear walls in the longitudinal direction for the design earthquake loads. All the walls were also found to be inadequate for out-of-plane loading. The gable walls are susceptible to fall out due to out-of-plane loading. It was found that there is not an adequate diaphragm from the 
light roof to support the heavy brick walls for the out-ofplane loading.

\subsection{Retrofit Procedures}

For sustainability, it was intended to retrofit the building to correct the identified deficiencies using available materials and currently common construction practices. Due to the available size and quality of bricks, it was necessary to fill some window openings and include wire mesh in the new confined masonry walls added to act as shear walls. It was also necessary to add the wire mesh in other walls to provide adequate strength for out-ofplane loading. New confining reinforced concrete columns, footing, and ring beams were added. Positive ties were provided from the wood trusses to the concrete ring beams. New horizontal steel trusses were added to act as a horizontal diaphragm and transfer the out-ofplane wall forces. The masonry gables were removed and replaced by light wood wall framing. The truss joints were reinforced with plywood gusset plates to improve their strength. New ceiling vertical supports and bracings were added. Confining columns were also added at wall openings. Fig. 19. shows the plan of the location of new retrofit elements.

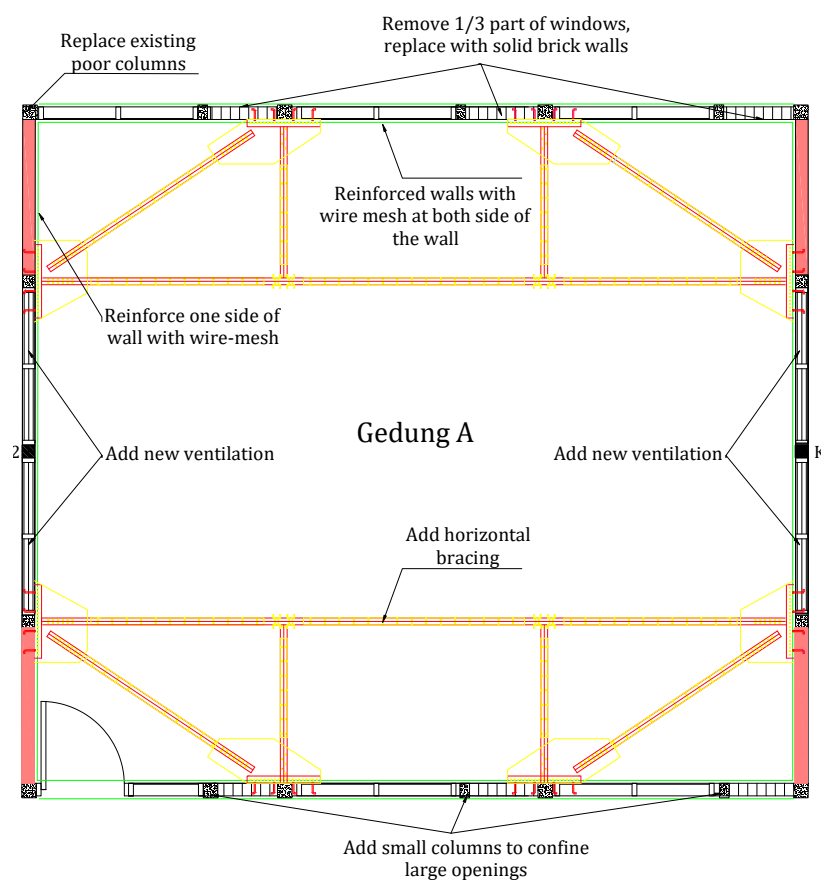

Fig. 19. Building A retrofit plan

\subsection{Retrofit Construction}

The retrofit construction was started by having the training of the construction crew to educate them on the level of details of construction, the quality of the construction materials and expected quality of work. There was regular supervision by engineers throughout the construction period.

1. Demolition: The locations of the new longitudinal shear wall panels and the gable portion of the transverse walls were demolished as shown in Fig. 20.

2. Foundation: Foundations were dug for the new confined masonry walls and confining columns and reinforced steel cages for columns and plinth beams placed as seen in Fig. 21.
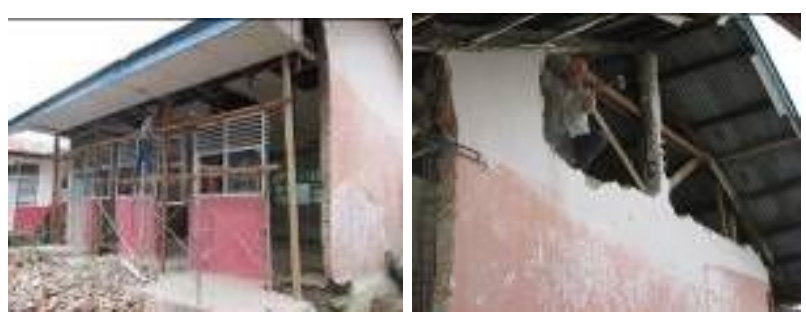

Fig. 20. Demolition of longitudinal walls (left) and gable of transverse walls (right)
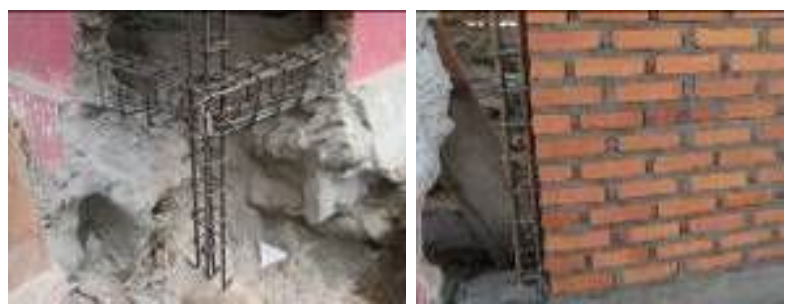

Fig. 21. New foundations at columns and walls

3. Seismic ties: Existing columns and beams use smooth round main structural reinforcements in both beams and columns. The lateral ties terminate with $90^{\circ}$ hooks. The ties are not suited for structural elements subjected to reversal loading. New details use deformed steel reinforcement longitudinal bars with lateral ties with $135^{\circ}$ hooks as seen in Fig. 22. in conformance to SNI requirements.
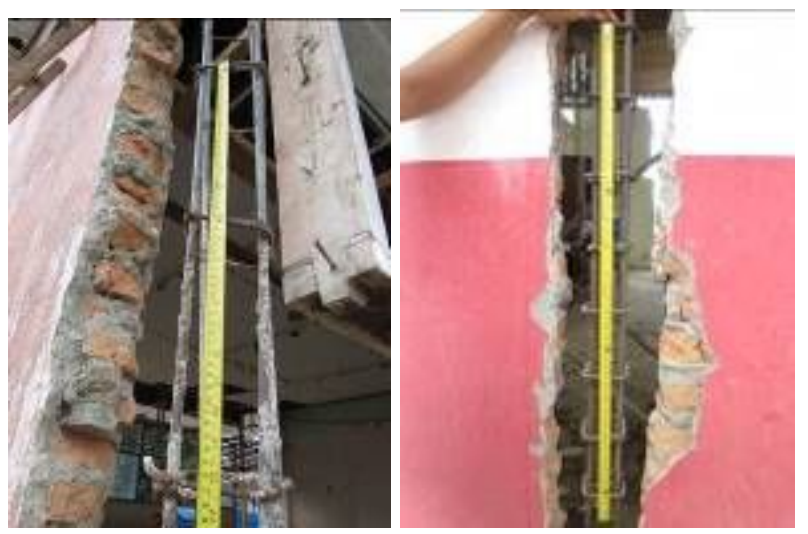

Fig. 22. Existing ties (left) and new seismic ties (right)

4. Ring beam: Reinforced concrete ring beams were added around the building and at cross walls at one elevation as seen on Fig. 23. Reinforcement detailing at the corners and intersections to provide adequate development lengths of the reinforcing bars was emphasized. Positive connections for the wood trusses to the ring beams was provided. 
5. Horizontal steel truss and wood truss retrofit: In order to provide a diaphragm to support the walls for out-of-plane loads, a new horizontal steel truss was installed. The existing wood truss was also retrofitted for strength by adding plywood gusset plates at the joints as seen in Fig. 24.
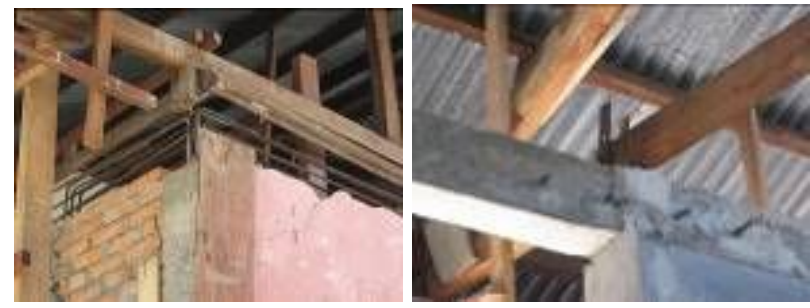

Fig. 23. Ring beam reinforcement (left) and wood truss connection (right)
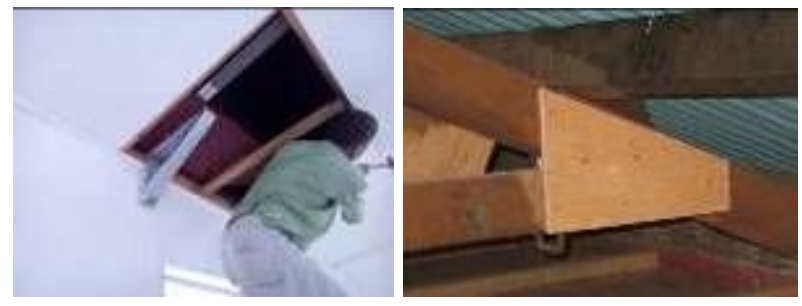

Fig. 24. New horizontal steel truss (left) and new wood truss gusset (right)

6. Wire mesh and light gable: Due to the weak strength of the bricks and the height of the walls, it was necessary to add wire mesh on either one side or both sides of the walls to resist both in-plane and out-ofplane forces in the walls. The existing heavy brick wall gables were removed and replaced by light wood gables as seen in Fig. 25.
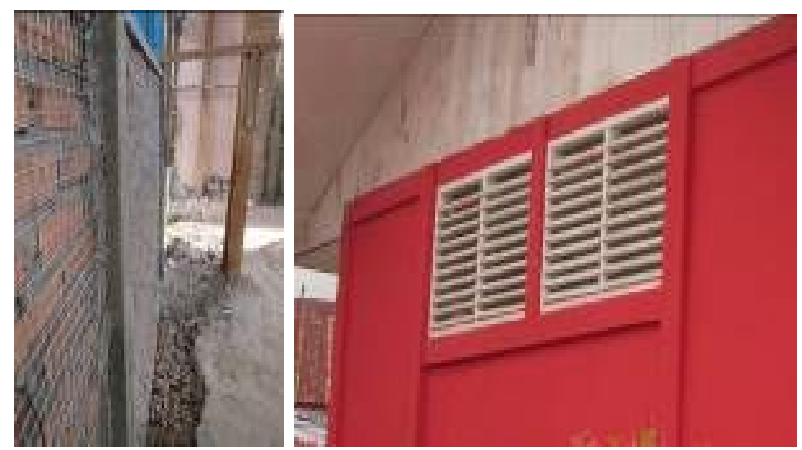

Fig. 25. Wire mesh on walls (left) and wood gable (right)

7. Completed retrofitted building: Architectural requirements for lighting and ventilation were observed as to what windows were filled by solid walls and where new ventilation was added. The ceiling was vertically supported and bracings were installed for the final and completed retrofitted building as seen in Fig. 26.
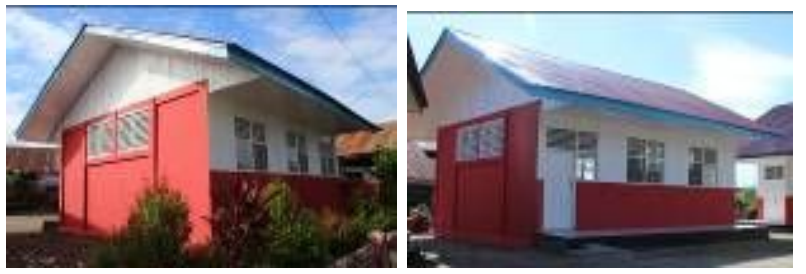

Fig. 26. Completely retrofitted Building A elevations

8. New safe classroom for a new generation: The completed and retrofitted classrooms meet current building code and Ministry of Education requirements for safety, lighting, and ventilation as seen in Fig. 27. The rooms are brighter and safe. The only left aspect is to provide a second exit and access ramps in order to make the building accessible to all students including those with physical disabilities.
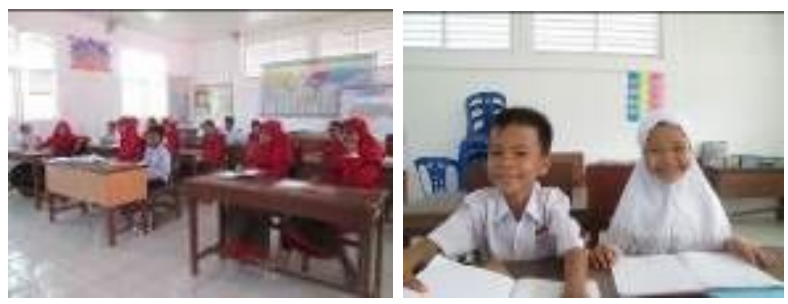

Fig. 27. Inside retrofitted classroom

\section{Conclusions}

The one-story single classroom school building was successfully retrofitted making it safe for design level earthquake. Both structural and non-structural elements were addressed. The evaluation and retrofit design method used here can be replicated to other school building of the same typology (which is a majority of schools). It is important that school heads, teachers, students, and community leaders be trained as to the potential hazards of existing school building structures. It is also urgent to have the retrofit of school buildings structures conducted in order to convert these structures as the desired community center and emergency evacuation centers. Access ramps and two exit doors are now mandated, [12], to make the community centers and emergency evacuation centers which need to be wheelchair accessible to all people including students with physical disabilities.

We would like to thank Thornton Tomasetti and the New Zealand Government for their generous donation of the funds needed to retrofit SDN 42 Korong Gadang, school buildings A and $\mathrm{B}$ in Padang, Indonesia.

\section{References}

1. Still Risky But Better Prepared-10 Years After the 2004 Sumatra Tsunami. [Online]. Available: http://www.air-worldwide.com/Publications/AIRCurrents/2014/Still-Risky-But-Better- 
Prepared $\%$ E2\%80\%9410-Years-After-the-2004Sumatra-Tsunami/

2. Natural Disasters in Indonesia. [Online]. Available: https://www.indonesiainvestments.com/business/risks/naturaldisasters/item 243

3. D.H. Natawidjaja, K. Bradley, M. R. Daryono, S. Aribowo, and J. Herrin, Late Quaternary Erruption of Ranau Caldera and new Geological Slip Rates of the Sumatran Fault Zone in Southern Sumatra, Indonesia, Geoscience Letters, paper 4:21 (2017)

4. SNI 1727-2013 Minimum load for the design of buildings and structures, National Standardization Agency (2013)

5. SNI 1726-2012 Procedures for earthquake resistance planning National Standardization Agency (2012)

6. SNI 7973-2013 Design specifications for wood construction National Standardization Agency (2013)

7. SNI 1729-2015 Specifications for structural steel structures, National Standardization Agency (2015)

8. PUIL SNI 04-0225-2011 General requirements of electrical installation, National Standardization Agency (2011)

9. SNI 03-7065-2005 Plumbing system planning, National Standardization Agency (2005)

10. Technical Guidance for New Elementary School Building, Year 2015, Ministry of Education and Culture (2015).

11. Technical Guidance for Renovations of Elementary School Building, Ministry of Education and Culture (2017)

12. Implementation of Disaster-Safe Schools, Year 2012, National Board for Disaster Management (2012)

13. Regulation of the Minister of National Education of the Republic of Indonesia Number 24 Year 2007 concerning Standard of Facilities and Infrastructure for Elementary School / Madrasah Ibtidaiyah (SD / MI), Junior High School / Madrasah Tsanawiyah (SMP / MTs) and Senior High School / Madrasah Aliyah (SMA / MA)

14. Regulation of the Minister of Education and Culture No. 61 of 2012 on the Amendment of the Regulation of the Minister of Education and Culture Nomore 56 Year 2011 on Technical Guidance of the Use of Special Allocation Fund for Education Sector of Fiscal Year 2012 For Primary School / Primary School Extraordinary.

15. Technical Guidance for Revitalization of Elementary School Building, Year 2015, Ministry of Education and Culture (2015).

16. Education in Indonesia. [Online]. Available: https://en.wikipedia.org/wiki/Education in Indonesi a.

17. A. Sakurai, M.B.F. Bisri, T. Oda, R.S. Oktari and Y. Murayama, Assessing school disaster preparedness by applying a comprehensive school safety framework: A case of elementary schools in Banda Aceh City, IOP Conference Series: Earth and Environmental Science, 56012021 (2017)

18. M.H. Pradono, Seismic Vulnerability Assessment on Schools and Public Markets in Jakarta using Rapid
Assessment Method, Natural Journals (ISSN: 25488635), Vol. 1, No. 1, pp. 49-54 (2017)

19. S. Anwar, The Mapping of Disaster Readiness of SSB (The Disaster Ready Schools) in The Coastal Area of Padang City, Indonesia, Sumatra Journal of Disaster, Geography and Geography Education, Vol. 1, No. 1, pp. 7-14 (June 2017) 